$a=5.56$ lbs. \pm 0.125 (possible error).

This result agrees closely with that calculated from the law of fatigue.

It should be added that a proposal was made by Dr. Haughton to Dr. Macalister to make the experiment conclusive by direct amputation of his scapula, a course which he, unreasonably, objected to, as he draws the line of "vivisection" at frogs.

\section{A LACUSTRINE VOLCANO}

$\mathrm{TN}$ a recent number of $L a$ Nature further details, furnished by the French Consul of San Salvador, M. J. Laferrière, are given concerning the recent volcanic phenomenon in Lake Ilopango in that State. The accompanying illustration, from a photograph, will show the nature of the crater which has risen in the midst of the lake. Earthquakes were felt in San Salvador in the first half of January of this year; there were three strong shocks, less violent, however, than those of 1876 . These earthquakes had their centre in the vicinity of Lake Ilopango, in the midst of which rose three volcanic openings connected with each other. This new crater, which, seen from a distance as in the illustration, appears a small islet, rises above the surface of the water, however, about twenty metres. An attempt was made to approach it in a boat, but the waters were all in a state of ebullition from contact with the burning rock, and gave off torrents of steam. An abundant column of smoke rose in the air, assuming the aspect of an immense cloud, which was seen from a great distance, and formed an imposing spectacle. The phenomenon was preceded by an exceptional rising of the lake, increased by the abundant winter rains. According to an old tradition the

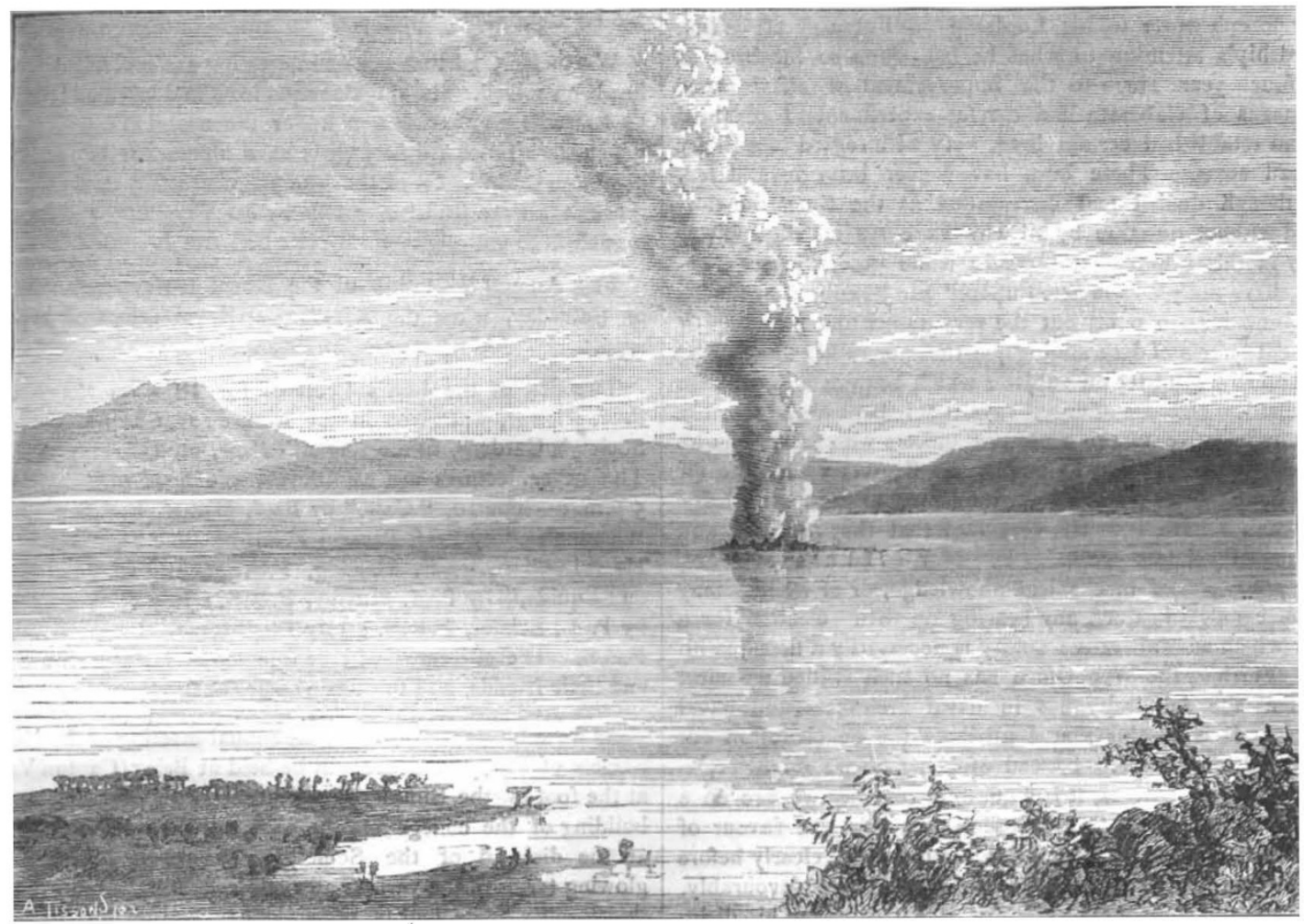

Aspect of the Volcano in Lake Ilopango. (From a Photograph.)

Spaniards maintain that when the lake rises earthquakes are to be feared. Formerly, also, it was the custom to dig trenches to facilitate the escape of the waters. This practice was followed without intermission for a century, and volcanic phenomena did not appear during all that time, The present phenomena seem to justify this tradition.

If it is difficult to explain the fact it is still interesting to remember that a great number of volcanoes are submarine, that others are found for the most part in islands or in maritime regions, and that water may be one of the feeders of volcanic fires. Lake Ilopango, also known as Lake Cojutepec, is, according to M. Laferrière, a sunk crater. It is in the volcanic line, and it is a general fact in Central America that lakes alternate with volcanic cones. The water of this lake is brackish, very bitter, and almost viscous. It gives off sometimes, here and there, bubbles of sulphohydric acid gas. The lake is about 12 kilometres long by 16 broad; the depth is unknown. It is about I2 kilometres from the city of San Salvador. The Consul of France in Guatemala, M. de Thiersant, states that Lake Ilopango has now a temperature of $38^{\circ} \mathrm{C}$. on its shore, and is in complete ebullition round the volcano. All the fishes are cooked and float upon the surface, with a great number of shellfish and other aquatic animals. The volcano continues to rise, and the level of the lake is being gradually lowered.

\section{NOTES}

THE candidates whose names we gave in a recent number (vol. xxi. p. 616) were elected Fellows of the Royal Society at the meeting of last Thursday. They are :-Dr. Clifford Allbutt, Prof. J. Attfield, Mr. H. E. Blanford, the Rev. W. H. Dallinger, Mr. Thiselton Dyer, Lieut.-Col. Godwin-Austen; the Bishop of Limerick, Prof. D. E. Hughes, Mr. H. M. Jeffery, 